\title{
Replication Protein A 70 kDa DNA-Binding Subunit
}

National Cancer Institute

\section{Source}

National Cancer Institute. Replication Protein A 70 kDa DNA-Binding Subunit. NCI

Thesaurus. Code C104757.

Replication protein A $70 \mathrm{kDa}$ DNA-binding subunit (616 aa, $\sim 68 \mathrm{kDa}$ ) is encoded by the human RPA1 gene. This protein is involved in stabilizing single-stranded DNA structures. 